\section{New Name 'Styer Group' Proposed for Interspecific Hybrids of Exacum Species Native to Sri Lanka}

\author{
Andrew Riseman ${ }^{1}$ \\ University of British Columbia Botanical Garden and Centre for Plant Research, \\ 6804 SW Marine Drive, Vancouver, BC, V6T $1 Z 4$
}

\section{V.A. Sumanasinghe}

Department of Agricultural Biology, Faculty of Agriculture, University of Peradeniya, Peradeniya, Sri Lanka

\section{Douglas Justice ${ }^{2}$}

University of British Columbia Botanical Garden and Centre for Plant Research, 6804 SW Marine Drive, Vancouver, BC, V6T $1 Z 4$

\section{Richard Craig}

Department of Horticulture, The Pennsylvania State University, University Park, PA 16802

Abstract. We propose the name Exacum Styer Group for an interspecific population derived from several Sri Lankan Exacum taxa. Confirmation of hybrid status was determined by the appearance of either unique trait combinations or intermediate forms of traits originally represented by individual native taxa. Through 12 sexual generations, the proposed cultivar-group continues to exhibit these unique traits and now forms a cohesive fertile population.

The genus Exacum L. (Gentianaceae Juss.) contains about 65 species, most of which are annual or perennial herbs (Klackenberg, 1985). Of the recognized species, only $E$. affine L., native to Socotra, has been successfully domesticated and introduced to commercial floriculture. However, several species and taxa native to Sri Lanka have been identified as potential new horticulture crops based on the presence of horticulturally desirable traits (Riseman and Craig, 1995). These traits include prolific flowering during the summer; abundant, large flowers (4 to $7 \mathrm{~cm}$ in diameter) that range in color from light blue to dark violet with contrasting bright yellow anthers; diverse growth habits from erect to decumbent; attractive, glossy green foliage; and efficient production attributes (e.g., easily propagated via vegetative cuttings). Unfortunately, no single species or taxon possesses sufficient desirable traits for either direct introduction or domestication. For example, E. macranthum Arn., known primarily for its large, dark blue-violet flowers, was identified over 30 years ago as a potential new horticultural crop (S. Suda, personal communication). Unfortunately, several independent

Received for publication 11 Dec. 2004. Accepted for publication 20 Mar. 2005. The authors would like to thank the H.M. Eddie Ornamental Plant Foundation and The Pennsylvania State University, Department of Horticulture, for their financial support. We would also like to thank Iain Taylor and Sean Graham for their critical review of the manuscript.

${ }^{1}$ Assistant professor of plant breeding. Author of correspondence; e-mail: ariseman@interchange. ubc.ca.

${ }^{2}$ Associate director and curator of collections.

${ }^{3} \mathrm{~J}$. Franklin Styer professor emeritus of horticultural botany. successful reciprocal crosses. breeding programs using this species as the sole germplasm source have yet to produce a commercially viable cultivar. Despite garnering significant attention for their beautiful flowers, failure to produce a worthy introduction was attributed to the lack of genetic variation of those nonfloral traits important for horticultural acceptance (e.g., height, branching habit and garden performance). Therefore, a controlled breeding program was initiated at The Pennsylvania State University using five taxa of Sri Lankan Exacum to combine desirable traits into genotypes worthy of commercialization.

Morphology of the primary hybrids was used to confirm hybrid status through the appearance of unique trait combinations not present in the parental taxa. In addition, the current population exhibits acceptable fertility levels (e.g., both pollen and ovule viability are typically at levels suitable for production of large progeny populations; however, overall fertility of individual genotypes varies) and important production characteristics (i.e., reliable vegetative reproduction, high density bench spacing). Based on these observations, we propose a new name for this group of hybrids derived from Exacum taxa native to Sri Lanka. The cultivar-group name 'Styer' is in tribute to J. Franklin Styer (Botany, University of Pennsylvania), who was recognized by Swarthmore College as one of the "...most creative and broadly competent horticultur-

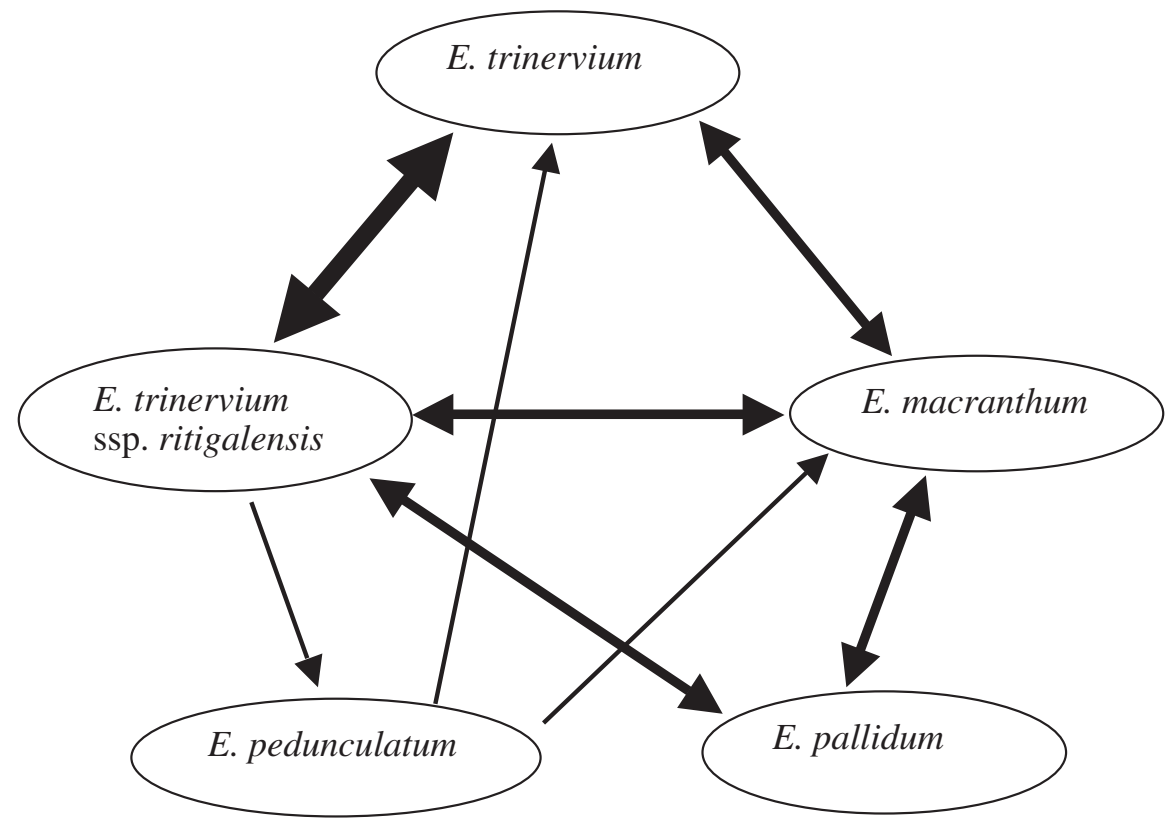

$$
\begin{aligned}
& \text { = production of many primary interspecific hybrids }(>50) \\
& \longrightarrow=\text { production of some primary interspecific hybrids }(>10<50) \\
& \longrightarrow \text { production of few primary interspecific hybrids }(<10)
\end{aligned}
$$

Fig. 1. Crossing diagram representing production of viable hybrids from among Sri Lankan Exacum taxa Arrow heads point to the taxon used as the seed parent in the cross. Double-headed arrows indicate 


\begin{tabular}{|c|c|c|c|c|c|c|}
\hline Species & $\begin{array}{l}\text { Stem shape } \\
\text { (ht at anthesis) }\end{array}$ & $\begin{array}{l}\text { Leaf shape } \\
(\mathrm{L} \times \mathrm{W})\end{array}$ & $\begin{array}{l}\text { Flower color } \\
\text { RHS code } \\
\text { (petal number) }\end{array}$ & $\begin{array}{l}\text { Calyx } \\
\text { lobe } \\
\text { length }\end{array}$ & $\begin{array}{l}\text { Petal apex } \\
\text { arrangement } \\
(\mathrm{L} \times \mathrm{W})\end{array}$ & $\begin{array}{l}\text { Anther } \\
\text { length }\end{array}$ \\
\hline E. macranthum & $\begin{array}{l}\text { Cylindrical } \\
(29-55 \mathrm{~cm})\end{array}$ & $\begin{array}{l}\text { Ovate to oval-suborbicular } \\
(4.5-9.7 \times 1.8-4.3 \mathrm{~cm})\end{array}$ & $\begin{array}{l}\text { Dark violet RHS 89B } \\
\text { (5-merous) }\end{array}$ & $8-9 \mathrm{~mm}$ & $\begin{array}{l}\text { Acuminate overlapping } \\
14-32 \times 8-25 \mathrm{~mm}\end{array}$ & $6-13 \mathrm{~mm}$ \\
\hline \multirow[t]{2}{*}{ E. pallidum } & Cylindrical with & & & & & \\
\hline & $\begin{array}{l}2 \text { opposite lines } \\
(17-48 \mathrm{~cm})\end{array}$ & $\begin{array}{l}\text { Ovate } \\
(3.0-7.5 \times 1.6-2.3 \mathrm{~cm})\end{array}$ & $\begin{array}{l}\text { Pale blue RHS 91C } \\
\text { (5-merous) }\end{array}$ & $9-10 \mathrm{~mm}$ & $\begin{array}{l}\text { Acute not overlapping } \\
10-11 \times 6-8 \mathrm{~mm}\end{array}$ & $2-4 \mathrm{~mm}$ \\
\hline E. pedunculatum & $\begin{array}{l}\text { Quadrangular } \\
(8-22 \mathrm{~cm})\end{array}$ & $\begin{array}{l}\text { Elliptic to ovate } \\
(1-2 \times 0.5-0.6 \mathrm{~cm})\end{array}$ & $\begin{array}{l}\text { Medium blue RHS 90D } \\
\text { (4-merous) }\end{array}$ & $3-4 \mathrm{~mm}$ & $\begin{array}{l}\text { Acute, reflexed overlapping } \\
6-8 \times 4 \mathrm{~mm}\end{array}$ & $4 \mathrm{~mm}$ \\
\hline E. trinervium & $\begin{array}{l}\text { Quadrangular } \\
\text { with wings } \\
(39-73 \mathrm{~cm})\end{array}$ & $\begin{array}{l}\text { Lanceolate to } \\
\text { narrowly elliptic } \\
(5.6-11.8 \times 1.8-4.7 \mathrm{~cm})\end{array}$ & $\begin{array}{l}\text { Medium to light blue } \\
\text { RHS 92B } \\
\text { (5-merous) }\end{array}$ & $7-10 \mathrm{~mm}$ & $\begin{array}{l}\text { Acute not overlapping } \\
6-16 \times 5-15 \mathrm{~mm}\end{array}$ & $6-13 \mathrm{~mm}$ \\
\hline $\begin{array}{l}\text { E. trinervium } \\
\text { ssp. ritigalensis }\end{array}$ & $\begin{array}{l}\text { Quadrangular } \\
\text { with wings } \\
(20-63 \mathrm{~cm})\end{array}$ & $\begin{array}{l}\text { Lanceolate to ovate } \\
\text { or narrowly elliptic } \\
(6.5-14.8 \times 1.3-4.3 \mathrm{~cm})\end{array}$ & $\begin{array}{l}\text { Medium to dark blue } \\
\text { RHS 93B-D } \\
\text { (5-merous) }\end{array}$ & $10-24 \mathrm{~mm}$ & $\begin{array}{l}\text { Acute overlapping } \\
6-25 \times 6-20 \mathrm{~mm}\end{array}$ & $6-13 \mathrm{~mm}$ \\
\hline$E$. Styer Group & $\begin{array}{l}\text { Cylindrical to } \\
\text { quadrangular, with } \\
\text { and without wings } \\
\text { or lines } \\
(12-36 \mathrm{~cm})\end{array}$ & $\begin{array}{l}\text { Lanceolate to ovate } \\
\text { or narrowly elliptic } \\
(5.5-11 \times 1.8-3.7 \mathrm{~cm})\end{array}$ & $\begin{array}{l}\text { Pale blue to dark violet } \\
\text { RHS 89B-C through 93A-C } \\
\text { (5-merous) }\end{array}$ & $3-24 \mathrm{~mm}$ & $\begin{array}{l}\text { Rhomboidial to broadly } \\
\text { obovate, overlapping or not } \\
20-28 \times 16-21 \mathrm{~mm}\end{array}$ & $8-18 \mathrm{~mm}$ \\
\hline
\end{tabular}

ists in North America." Styer helped write the first edition of the International Code of Nomenclature for Cultivated Plants was a strong supporter of horticultural education and introduced many plant cultivars including Cedrus deodara (D. Don) G. Don 'Kashmir', Ilex crenata Thunb. 'Green Island', I. crenata 'Birmingham', and Berberis $\times$ gladwynensis E. Anders.'William Penn'.

\section{Origin}

The taxonomic treatment of Sri Lankan Exacum has been revised three times during the past 20 years (Cramer, 1981; Klackenberg, 1985; Sumanasinghe, 1986). The primary difference among these treatments is centered on taxon rank, not taxon recognition (except for Klackenberg's treatment of E. trinervium (L.) Druce ssp. ritigalensis (Willis) Cramer which he collapsed into E. trinervium). We have chosen to use the treatment of Sumanasinghe for several reasons. As the most recent, Sumanasinghe had the advantage of reviewing the prior research and further refining descriptions based on his research using cytogenetics, isozyme profiles, and crossability (prior treatments were based only on anatomy and morphology). In addition, research on hybrid fertility (Riseman, 1990) and edaphic conditions of each taxon's native habitat (Riseman, 1997), support Sumanasinghe's conclusions on taxon identity and rank.

The following taxa were collected from their native habitats in 1983 and 1984 and used in controlled hybridizations: $E$. pedunculatum L., E. macranthum Arn., E. pallidum Trimen., E. trinervium (L.) Druce, and E. trinervium ssp. ritigalensis (Willis) Cramer. All taxa are considered cross-pollinated in nature. However, despite this and the production of inter-taxa hybrids from hand-pollinations, natural hybrids among these taxa are suspected to exist only between E. pallidum and E. trinervium (Klackenberg, 1983). Primary interspecific hybrids were produced in 1984 and 1985 with varying success, depending on the parental combination (Sumanasinghe, 1986)(Fig. 1). These primary hybrids were then incorporated into a pedigree breeding program where in each generation, superior progeny were identified and used as the following generation's parents. Through 12 generations beyond the primary hybrids, we have selected for fertility (individual genotypes' pollen viability range between $0 \%$ to $96 \%$; data not shown), greenhouse production traits, and combinations of horticultural traits that are indicative of hybrid status.

\section{Description}

The distinguishing traits among the original taxa used in the breeding program and the distinguishing traits of the Styer Group are summarized in Table 1. Color descriptions are based on the RHS Color Chart (Royal Horticulture Society, 1998). Through repeated cycles of seed production and selection, the proposed cultivar-group includes all distinguishing traits identified in the original populations. However, as a result of the initial interspecific hybridizations and subsequent breeding, these

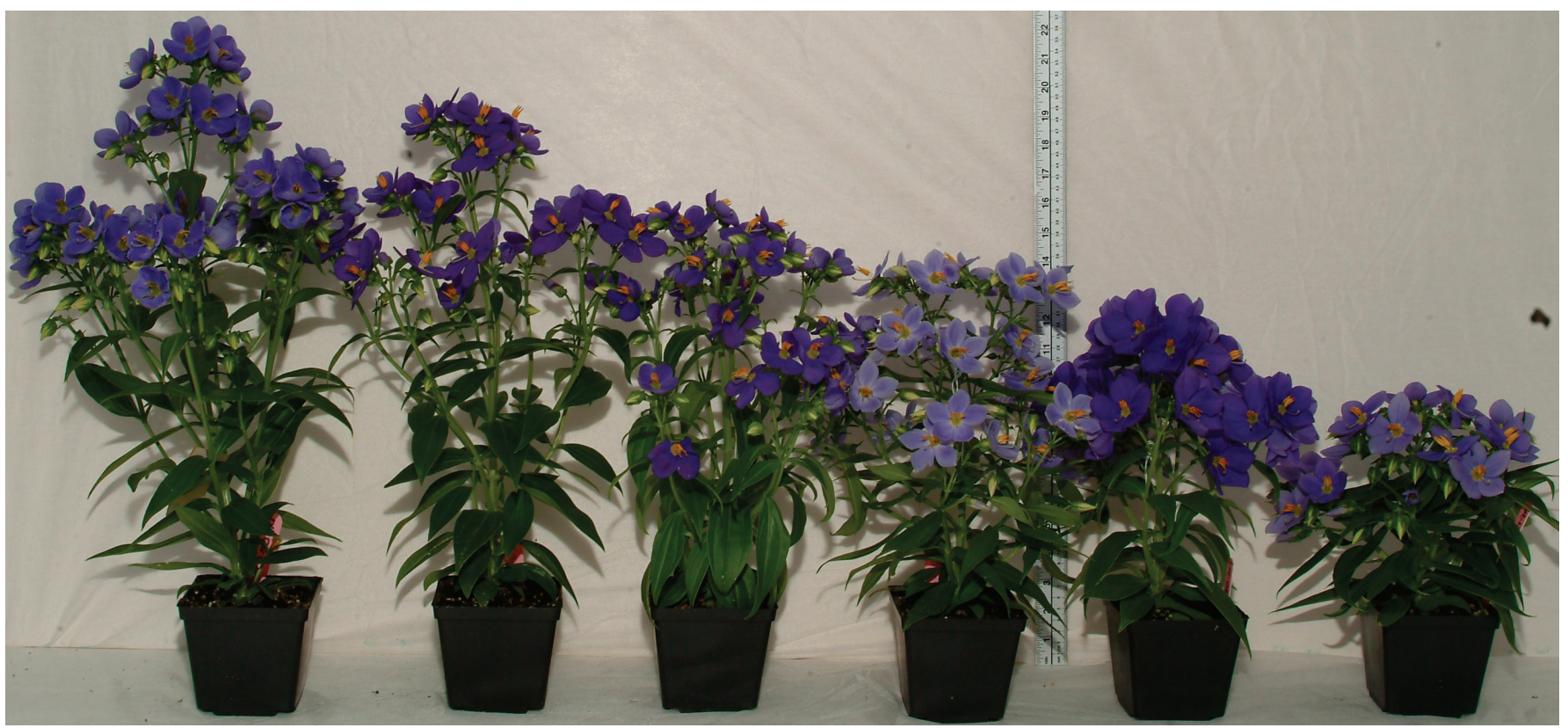

Fig. 2. Individuals of Exacum Styer Group representing the range of plant habits displayed from 12th generation hybrids. 


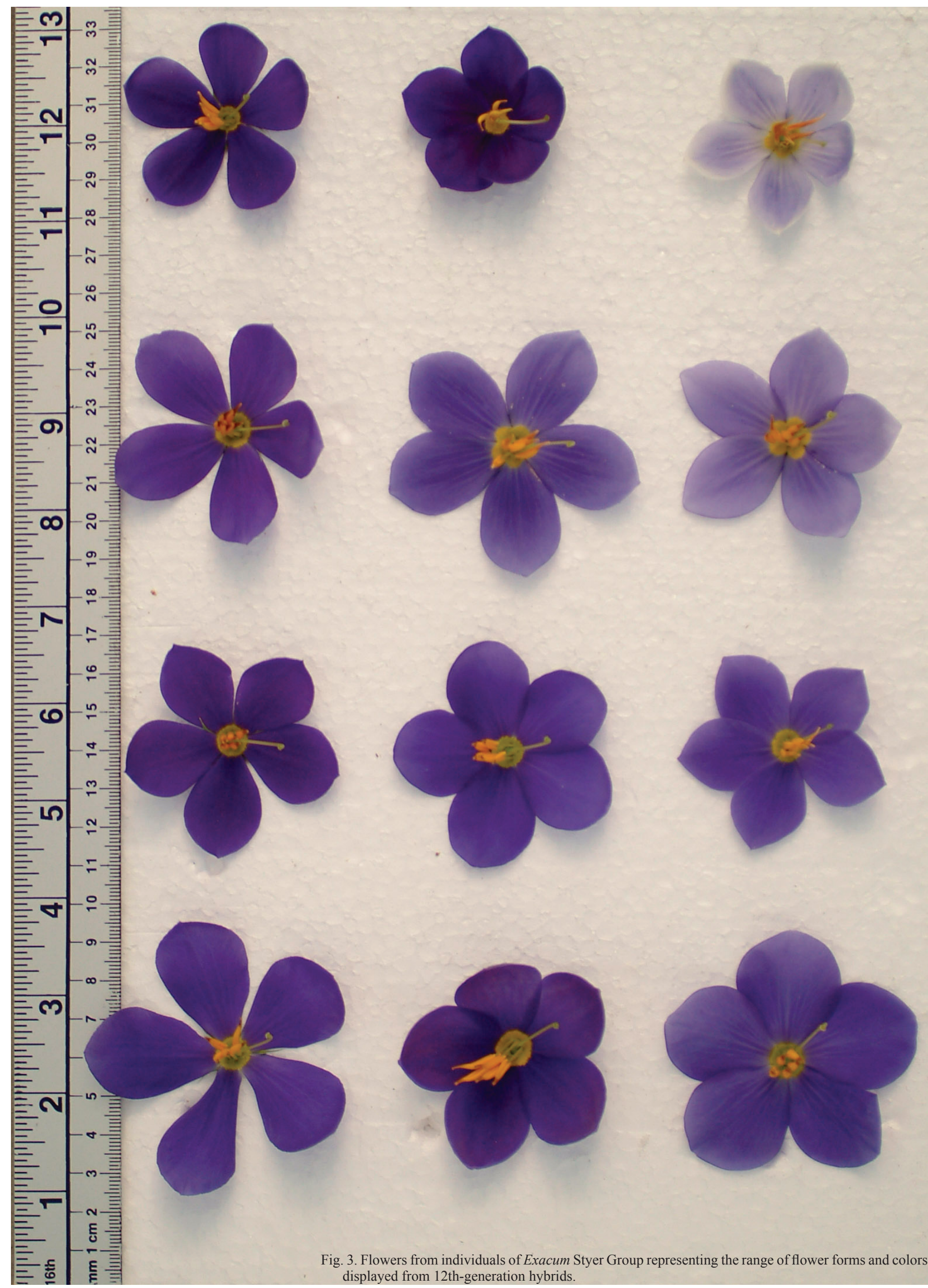


traits are now expressed in novel combinations and as intermediate forms not displayed in the original taxa. Traits critical in the delineation of the original taxa include: stem shape, leaf shape, flower color, calyx length, petal shape, and anther length (Table 1). In addition, important horticultural traits contributed to the cultivar-group by individual species include dark blue-violet, acuminate petals (E. macranthum), pale-blue, nonoverlapping petals (E. pallidum), short plant stature and increased branching (E. pedunculatum), enhanced flower production and upright growth habit (E. trinervium), and large broadly acute petals (E. trinervium ssp. ritigalensis). The range of phenotypes currently represented in the proposed cultivar-group is presented for plant conformation (Fig. 2) and flower form (Fig. 3). Voucher specimens representing the Styer Group are maintained at the University of British Columbia Herbarium.

\section{Culture}

Asexual reproduction. Exacum Styer Group is easily propagated throughout the year by stem cuttings. However, higher rooting percentages are observed when cuttings are harvested from nonflowering stock plants. Rooted cuttings are obtained within 4 to 6 weeks from cuttings 2 to 3 nodes in length, basally treated with $1 \%$ IBA in talc, and placed in cell packs filled with a well-drained substrate under intermittent mist. Rooting percentages range from $50 \%$ to $100 \%$ depending on genotype and reproductive status of the stock plant.

Growth medium and fertilization. Plants perform well in a quick draining peat-based medium. Depending on water quality, media $\mathrm{pH}$ can be managed through the use of fertilizer; higher ammonium:nitrate ratio will help to maintain a low media $\mathrm{pH}$. Excellent results have been obtained fertigating with acidifying fertilizers high in ammonical nitrogen, used at a rate of 150 to $200 \mathrm{mg} \cdot \mathrm{kg}^{-1}$ total nitrogen. The optimal media $\mathrm{pH}$ range is 5.0 to 6.0 and that for electrical conductivity (EC) is 1 to $2.25 \mathrm{dS} \cdot \mathrm{cm}^{-1}$.

Irrigation. Plants perform best when grown on the 'dry side' but without undo wilting. Typically, excessive irrigation or a severe drought followed by excessive irrigation leads to increased susceptibility to root pathogens. Also, plant growth is enhanced by periodically wetting the foliage with either water or a dilute fertilizer solution.

Pest management. Exacum Styer Group is susceptible to attack by several plant pests. Greenhouse whitefly (Trialeurodes vaporariorum Westwood) can be controlled through applications of several commercial pesticides; however, Malathion has been shown to have phytotoxic effects on mature buds and open flowers. Fungus gnats (Bradysia spp. Winnertz) can be controlled through the introduction of commercially available parasitic nematodes (Steinernema Travassos) or application of a Bti (Bacillus thuringiensis Berliner spp. israelensis) based product. In addition, the root pathogens Pythium Pringsh., Phytophthora deBary., and Fusarium Link ex Fr. can infect $E$. Styer Group. These diseases can be controlled though a combination of cultural modification (e.g., less frequent irrigations) and medium drenches with commercial fungicides.

Environmental conditions and flowering time. Exacum Styer Group prefer warm temperatures and high humidity during production. Maintaining aerial temperature between 18 to $26{ }^{\circ} \mathrm{C}$ day/ $/ 6$ to $20{ }^{\circ} \mathrm{C}$ night and relative humidity between $70 \%$ to $85 \%$ throughout the production cycle gives good results. Photoperiod control is not required for flowering; however, flowering time will vary based on genotype and will decrease with increasing light intensities. The earliest genotypes flower 6 to 8 weeks after transplanting into a finishing container (e.g., 10 to $15 \mathrm{~cm}$ ) while the latest genotypes flower between 16 to 20 weeks following transplanting. During naturally low light months, supplemental irradiance promotes earlier and more robust flowering for all genotypes.

\section{Summary}

The consistent desire for new and interesting horticultural crops prompted us to evaluate the commercial potential of SriLankan Exacum taxa, close relatives of $E$. affine (Persian violet). Based on initial evaluations, we concluded no single taxon had sufficient horticultural merit to begin commercialization. When these taxa were intercrossed, however, the interspecific populations displayed novel forms worthy of continued breeding. Through several sexual generations, the resulting population has distinguished itself from the original taxa by displaying novel forms and full sexual compatibility. We propose the new name 'Styer Group' for the selections from this interspecific population, with the following description (note: cultivated selections designated from interspecific crosses with Sri Lankan taxa Exacum macranthum, E. pallidum, E. pedunculatum, and E. trinervium):

Botanical description. Plants decumbent to erect; stems cylindrical to quadrangular, with wings present or lacking. Leaves glossy green, lanceolate to ovate or narrowly elliptic; leaf tips acute to acuminate, leaf bases cuneate to rounded. Flowers blue to violet, pale to dark hues, flattened to cup-shaped or rarely with petals reflexed, corolla base short tubular, the petals rhomboidial to broadly obovate, overlapping along their entire length to overlapping only at their broadest point or not overlapping. Anthers bright yellow, 8 to $18 \mathrm{~mm}$ long.

Due to the interspecific origin of these plants, heterozygosity remains high and we anticipate initial introductions to be vegetatively propagated.

\section{Literature Cited}

Cramer, L. H. 1981. Gentianaceae, p. 55-66. In: M.D. Dassanayake (ed.). A revised handbook to the flora of Ceylon. vol. 3. Amerind Publ. Co. New Delhi.

Klackenberg, J. 1983. A reevaluation of the genus Exacum (Gentianaceae) in Ceylon. Nord. J. Bot. 3:355-370.

Klackenberg, J. 1985. The genus Exacum (Gentianaceae). Opera botanica, p. 1-144. AiO Print Ltd. Copenhagen.

Riseman, A. 1990. Examination of the morphology and reproductive biology of interspecific hybrids of Exacum. MS thesis. Pa. State Univ., University Park.

Riseman, A. 1997. Ecology, physiology, and genetics of zinc nutrition in Sri Lankan Exacum hybrids. PhD thesis. Pa. State Univ., University Park.

Riseman, A. and R. Craig. 1995. Interspecific Exacum Hybrids- Novel germplasm for the production of a new floricultural crop. XVIIIth EUCARPIA Symposium Section Ornamentals, Tel Aviv, Israel. 5-9 Mar. 1995. Acta Hort. 420:132-134.

Royal Horticultural Society. 1998. Royal Horticultural Society colour chart. Royal Hort. Soc., London.

Sumanasinghe, V.A. 1986. Electrophoretic, cytogenetic, crossability, and morphological studies of Exacum (Gentianaceae). PhD thesis. Pa. State Univ., University Park. 